\title{
Peningkatan Literasi Sains Melalui Pembelajaran Berbasis Scientific Approach
}

\author{
Arfiati Ulfa Utami ${ }^{1)}$, Selly Candra Citra Murti ${ }^{2)}$ \\ ${ }^{1}$ Fakultas Matematika dan Ilmu Pengetahuan Alam, Universitas PGRI Banyuwangi \\ Email ${ }^{1}$ : fieare@ymail.com \\ ${ }^{2}$ Fakultas Matematika dan Ilmu Pengetahuan Alam, Universitas PGRI Banyuwangi \\ Email²: sellycandra.18@gmail.com
}

\begin{abstract}
Penelitian ini bertujuan untuk mengetahui hasil penerapan pembelajaran berbasis scientific approach yang digunakan untuk meningkatkan literasi sains siswa. Penelitian ini merupakan Quasi eksperimen dengan pretest-posttest control group design untuk mengetahui hasil penerapan pembelajaran berbasis scientific approach terhadap literasi sains siswa. Populasi dalam penelitian ini adalah seluruh siswa kelas VII SMPN 1 Srono dengan sampel kelas VII.1 sebagai kelas kontrol dan kelas VII.2 sebagai kelas eksperimen. Penentuan sampel tersebut menggunakan teknik purposive sampling dengan pertimbangan tertentu. Instrumen penelitian berupa lembar wawancara dan tes literasi sains. Hasil penerapan pembelajaran berbasis scientific approach dan perangkat pembelajarannya diperoleh peningkatan literasi sains berdasarkan nilai $\mathrm{N}$-gain pada kelaskontrol sebesar (kategori rendah), sedangkan pada kelas eksperimen sebesar (kategori sedang). Hasil penelitian dan pembahasan disimpulkan bahwa penerapan pembelajaran berbasis scientific approach dan perangkat pembelajaran yang diperoleh dapat digunakan untuk meningkatkan literasi sains siswa
\end{abstract}

Keywords: literasi sains, pembelajaran berbasis scientifi approach, perangkat pembelajaran

\section{PENDAHULUAN}

Memasuki perkembangan abad 21 menuntut semua masyarakat untuk mampu memiliki kecakapan hidup, dimana individu secara kreatif mampu menemukan masalah serta mengatasi masalah tersebut secara cerdas. Menurut Noviana dalam penelitiannya (2017) pesatnya perkembangan sains dan teknologi di abad 21 menuntut manusia semakin bekerja keras menyesuaikan diri dalam segala aspek kehidupan. Salah satu kunci sukses menghadapi tantangan abad 21 adalah "melek sains", individu yang melek sains dapat menggunakan informasi ilmiah yang dimilikinya untuk mengatasi masalah dalam kehidupan sehari-hari serta menghasilkan produk-produk ilmiah yang bermanfaat.

Semakin berkembangnya Ilmu Pengetahuan dan Teknologi (IPTEK), masyarakat juga harus siap menghadapi tantangan dunia, seperti pasar bebas. Masyarakat Indonesia dikhawatirkan akan gagal memasuki pasar bebas pada tahun 2020. Didasarkan pada kenyataan bahwa literasi sains pada masyarakat tergolong rendah.
Menurut Hurt dalam Bahriah (2012) literasi sains adalah tindakan memahami sains dan mengaplikasikan bagi kebutuhan masyarakat. Literasi sains diartikan juga sebagai kapasitas untuk menggunakan pengetahuan ilmiah, mengidentifikasi pertanyaan dan menarik kesimpulan berdasarkan atas fakta dan data untuk memahami alam semesta dan membuat keputusan dari perubahan yang terjadi karena aktivitas manusia. Literasi sains sangat penting untuk dimiliki peserta didik sebagai bekal menghadapi tantangan perkembangan abad 21.

Literasi sains menurut PISA yang dikutib oleh Yuliati (2017) diartikan sebagai "the capacity to use scientific knowledge, to identify questions and to draw evidence-based conclusions in order to understand and help make decisions about the natural world and the changes made to it through human activity".

Holbrook yang dikutib oleh Yuvita (2012) dalam jurnalnya the meaning of science, menyatakan literasi sains berarti penghargaan pada ilmu pengetahuan dengan cara meningkatkan komponen 
komponen belajar dalam diri agar dapat memberi kontribusi pada lingkungan sosial. Secara umum literasi sains memiliki beberapa komponen, yaitu 1 mampu membedakan mana konteks sains dan mana yang bukan konteks sains 2 mengerti bagian-bagian dari sains dan memiliki pemahaman secara umum ap likasi sains 3 memiliki kemampuan untuk menerapkan pengetahuan sains dalam pemecahan masalah 4 mengerti karateristik dari sains dan 5 mengetahui manfaat dan resiko yang dibutuhkan oleh sains. Jika dikaitkan dengan aspek pengetahuan taksonomi Bloom, literasi sains lebih dominan dengan pengetahuan applying, analysing dan evaluating. Peningkatan literasi sains secara langsung dapat meningkatkan kemampuan berpikir tingkat tinggi.

Kemampuan literasi sains yang lemah merupakan salah satu temuan hasil studi komperatif yang dilakukan PISA tahun 2000, ini terungkap dari nilai rerata tes literasi sains anak Indonesia adalah 393 yang menempatkan Indonesia pada peringkat ke-38 dari 41 negara peserta PISA. Hasil temuan mengindikasikan bahwa literasi sains Indonesia masih rendah. Sekolah harus dapat menciptakan proses pembelajaran yang tidak hanya membuat siswa menguasai ilmu pengetahuan tetapi bagaimana siswa tersebut mengimplementasikan dan memanfaatkan ilmu pengetahuan untuk menghadapi kehidupan abad 21, salah satunya melalui inovasi pembelajaran. Pembelajaran berbasis scientific approach adalah pendekatan ilmiah yang mendorong siswa untuk mampu memahami, menerapkan dan mengembangkan pola pikir yang rasional. Dalam kurikulum 2013, aktivitas pendekatan saintifik meliputi mengamati, menanya, mencoba, mengolah, menyaji, menalar, dan mencipta.

Berdasarkan alasan tersebut, maka penelitian ini memaparkan hasil peningkatan literasi sains menggunakan inovasi pembelajaran berbasis scientific approach.

\section{METODE PENELITIAN}

Penelitian ini merupakan Quasi experiment dengan pretest-posttest control group design. Populasi dalam penelitian ini adalah seluruh siswa kelas VII SMP Negeri 1 Srono. Penentuan sampel menggunakan teknik purposive sampling dengan pertimbangan tertentu. Adapun sampel yang digunakan adalah kelas VII.1 sebagai kelas kontrol sebanyak 30 siswa dan kelas VII.2 sebagai kelas eksperimen sebanyak 32 siswa. Data penelitian diperoleh dari tes, angket dan wawancara. Instrumen penelitian berupa lembar tes literasi sains, angket dan wawancara. Data penelitian ini diperoleh dari nilai pretest dan posttest kelas kontrol dan eksperimen. Penilaian berdasarkan pada indikator aspek kompetensi pada literasi sains.

\section{HASIL DAN PEMBAHASAN}

Menurut Kurikulum 2013 pembelajaran dengan pendekatan saintifik adalah proses pembelajaran yang dirancang sedemikian rupa agar peserta didik secara aktif mampu untuk mengkonstruk konsep, hukum atau prinsip melalui tahapan-tahapan mengamati, merumuskan masalah, mengajukan hipotesis, mengumpulkan data, menganalisis data, menarik kesimpulan dan mengkomunikasikan konsep yang ditemukan. Pendekatan saintifik dimaksudkan untuk memberi pemahaman siswa untuk mengenal, memahami materi menggunakan pendekatan ilmiah, sehingga dapat melatih literasi sains siswa. Indikator literasi sains pada penelitian ini meliputi mengamati, merumuskan masalah, memprediksi, mengumpulkan dan mengolah data, menarik kesimpulan, dan aplikasi konsep. Berdasarkan National teacher association yang dikutip oleh Evi (2012) mengemukakan bahwa seseorang yang literat sains adalah orang yang menggunakan konsep sains, keterampilan proses dan nilai dalam membuat keputusan dalam kehidupan seharihari yang berhubungan dengan lingkungan, teknologi, dan masyarakat. Pembelajaran dengan menerapkan pembelajaran menggunakan pendekatan saintifik yang dilakukan akan memberikan pengaruh terhadap kemampuan literasi sains pada siswa. Data hasil evaluasi pembelajaran yang diperoleh selanjutnya dianalisis dengan membandingkan nilai pre test, post test dan $\mathrm{N}$ gain. Peningkatan literasi sains sebelum dan setelah implementasi menggunakan buku paket BSE pada kelas kontrol dan menggunakan bahan ajar IPA menggunakan 
pendekatan saintifik pada kelas eksperimen dapat dilihat pada Tabel 1.

Tabel 1. Hasil Peningkatan Literasi Sains Siswa Pada Kelas Kontrol dan Eksperimen

\begin{tabular}{lllll}
\hline Kelas & Pretest & Posttest & N-gain & Kriteria \\
\hline Kontrol & 65,58 & 73,87 & 0,240 & Rendah \\
Eksperimen & 65,25 & 86,32 & 0,606 & Sedang \\
\hline
\end{tabular}

Data yang disajikan dalam tabel 1 menunjukkan hasil penelitian bahwa bahan ajar menggunakan pendekatan saintifik telah mampu meningkatkan literasi sains siswa pada kelas eksperimen. Harga N-gain pada kelas kontrol 0,240 sedangkan pada kelas eksperimen harga $\mathrm{N}$-gain 0,606. Peningkatan literasi sains siswa pada kelas kontrol mencapai 0,240 termasuk dalam kategori rendah, sedangkan pada kelas eksperimen mencapai 0,606 yang termasuk dalam kategori sedang. Berikut adalah harga $\mathrm{N}$-gain terhadap setiap indikator literasi sains pada kelas kontrol dan eksperimen disajikan pada Tabel 2.

Tabel 2. Harga N-Gain Terhadap Indikator Literasi Sains

\begin{tabular}{|c|c|c|}
\hline $\begin{array}{c}\text { Indikator Literasi } \\
\text { Sains }\end{array}$ & Kontrol & Eksperimen \\
\hline Mengamati & 0,231 & 0,631 \\
\hline $\begin{array}{l}\text { Merumuskan } \\
\text { masalah }\end{array}$ & 0,142 & 0,392 \\
\hline Memprediksi & 0,165 & 0,410 \\
\hline $\begin{array}{l}\text { Mengumpulkan } \\
\text { dan mengolah } \\
\text { data }\end{array}$ & 0,186 & 0,510 \\
\hline $\begin{array}{l}\text { Menarik } \\
\text { kesimpulan }\end{array}$ & 0,210 & 0,553 \\
\hline Aplikasi konsep & 0,192 & 0,482 \\
\hline
\end{tabular}

Indikator literasi sains meliputi: mengamati, merumuskan masalah, memprediksi, mengumpulkan dan mengolah data, menarik kesimpulan, dan aplikasi konsep. Berdasarkan Tabel 2 harga N-gain tertingi pada kelas kontrol 0,231 dan kelas eksperimen 0,631 yaitu pada indikator mengmati sedangkan harga N-Gain terendah pada kelas kontrol 0,142 dan kelas eksperimen 0,392 yaitu pada indikator merumuskan masalah.
Peningkatan literasi sains siswa setelah menggunakan perangkat pembelajaran berbasis scientific approach ditunjukkan dari hasil perhitungan N-gain. Menurut penelitian Yuliati indikator keberhasilan dalam penelitian ini adalah jika nilai $\mathrm{N}$-gain lebih besar dari 0,3 . Hasil perhitungan $\mathrm{N}$-gain pada kelas eksperimen diperoleh nilai $\mathrm{N}$-gain $>3$ maka dapat disimpulkan bahwa perangkat pembelajaran IPA melalui pembelajaran berbasis scientific approach efektif digunakan dalam pembelajaran dalam upaya meningkatkan literasi sains siswa.

Hasil penelitian tidak jauh beda dengan penelitian yang dilakukan oleh Perwitasari (2016) yaitu peningkatan literasi sains dengan menerapkan pembelajaran konsep energi dan perubahannya bermuatan etnosains dan perangkat pembelajarannya diperoleh berdasarkan nilai $\mathrm{N}$-gain pada kelas kontrol sebesar 0,164 (kategori rendah), sedangkan pada kelas eksperimen sebesar 0,443 (kategori sedang). Analisis dengan uji t berdasarkan hasil pretest diperoleh nilai Sig. (2-tailed) sebesar 0,670 >0,05 menunjukkan tidak adanya perbedaan yang signifikan pada nilai pretest kedua kelas, sedangkan nilai posttest antar kelas diperoleh Sig. (2-tailed) sebesar $0,000<0,05$ menunjukkan ada perbedaan yang signifikan nilai posttest kedua kelas. Hasil penelitian disimpulkan bahwa penerapan pembelajaran konsep energi dan perubahannya bermuatan etnosains pengasapan ikan dapat digunakan untuk meningkatkan literasi sains siswa.

Perbedaan hasil literasi sains siswa terlihat saat proses pembelajaran di kelas kontrol maupun eksperimen. Pada kelas kontrol sebagaian siswa belum mampu untuk merumuskan masalah, memprediksi, mengumpulkan data serta belum mampu mengaplikasikan konsep. Pembelajaran pada kelas eksperimen sebagaian siswa sudah mampu untuk merumuskan masalah, serta mampu mengaplikasikan konsep sains. Berdasarkan hasil observasi pada kelas 
eksperimen, siswa lebih senang pada tahap mengamati. Berdasarkan hasil N-gain tertinggi pada kelas eksperimen memperlihatkan kemampuan guru dalam memfasilitasi peserta didik untuk melakukan pengamatan, melatih mereka untuk memperhatikan (melihat, membaca, mendengar) hal yang penting dari suatu benda atau objek. Siswa merasa senang dalam tahap mengamati ini, karena siswa mengamati benda atau peristiwa yang secara langsung. Berdasarkan pada kutipan Kemdikbud (2013) metode mengamati mengutamakan kebermaknaan proses pembelajaran (meaningfull learning). Metode ini memiliki keunggulan tertentu, seperti menyajikan media objek secara nyata, peserta didik senang dan tertantang serta mudah pelaksanaanya. Metode mengamati sangat bermanfaat bagi pemenuhan rasa ingin tahu peserta didik, sehingga proses pembelajaran memiliki kebermaknaan yang tinggi sehingga literasi sains dapat meningkat.

Perbedaan kemampuan literasi sains juga ditunjukkan pada hasil penelitian Ariningtyas (2017) menunjukkan bahwa Lembar Kegiatan Siswa (LKS) bermuatan etnosains untuk meningkatkan literasi sains pada materi hidrolisis garam yang dikembangkan dapat meningkatkan aspek konten siswa pada kelas eksperimen dengan perolehanN-gain sebesar 0,71 dalam kategori tinggi, aspekkonteks siswa dengan perolehan $\mathrm{N}$-gain sebesar 0,73 dalam kategori tinggi dan aspek proses sains siswa dengan perolehan $\mathrm{N}$-gain sebesar 0,50 dalam kategori sedang. Siswa memberikan respon positif terhadap implementasi LKS bermuatan etnosains pada materi hidrolisis garam yang dikembangkan dalam kategori baik yaitu sebesar 77,6\%

Bahan ajar yang baik akan menunjang pembelajaran yang efektif. Menurut Prastowo
(2011) bahwa bahan ajar memiliki kontribusi yang besar bagi keberhasilan proses pembelajaran yang dilakukan. Menurut National Centre For Competency Based Training dalam Prastowo (2011), bahan ajar adalah segala bentuk bahan yang digunakan untuk membantu guru dalam melaksanakan proses pembelajaran di kelas. Maka dari itu guru harus mampu menyusun bahan ajar yang tepat untuk siswa agar kegiatan pembelajaran tidak membosankan.

Aspek melek ilmiah menyinggung penerapan atau aplikasi sains dan bagaimana teknologi membantu dan justru menggangu manusia. Hal ini juga menyinggung soal issu sosial dan karir. Siswa menerima informasi tersebut dan umumnya tidak harus menemukan atau menyelidiki (Perwitasari, 2016). Peningkatan literasi sains menggunakan bahan ajar IPA pada penelitian Nisa (2015) melalui modul terintegrasi etnosains dalam pembelajaran berbasis masalah mampu untuk meningkatkan literasi sains siswa. Hasil penelitian menunjukkan bahwa rata-rata hasil belajar kelas eksperimen sebesar $81,38 \%$ sedangkan rata-rata kelas kelas kontrol sebesar 77,83 dengan $\mathrm{N}$-gain kelas eksperimen sebesar 0,65 dengan kategori sedang dan kelas kontrol 0,56 kategori sedang.

\section{KESIMPULAN}

Berdasarkan pada pembahasan yang telah diuraikan di atas, maka dapat disimpulkan bahwa kemampuan literasi melalui pembelajaran berbasis scientific approach dan perangkat pembelajaran menunjukkan perbedaan yang signifikan denagn kelas kontrol yang hanya menggunakan buku paket sebagai bahan ajar di kelas. Hasil implementasi pembelajaran berbasis scientific approach dn perangkat pembelajaran ini terbukti dapat meningkatkan literasi sains siswa.

Sebagai tindak lanjut dari penelitian ini, maka dapat dikemukakan beberapa saran agar menghasilkan dampak yang sesuai dengan tujuan pembelajaran yang diinginkan maka penerapan perangkat pembelajaran IPA 
berbasis scientific approach digunakan dengan pengelolaan waktu yang cukup dan efisien. Guru juga perlu menambah wawasan tentang kearifan lokal yang dimiliki oleh daerahnya sehingga pembelajaran lebih menarik dan inovatif.

\section{REFERENSI}

Andi Prastowo. 2011. Panduan Kreatif Membuat Bahan Ajar Inovatif. Yogyakarta: Diva Press

Ariningtyas, Agnes., dkk. 2017. Efektivitas Lembar Kerja Siswa Bermuatan Etnosains Materi Hidrolisis Garam untuk Meningkatkan Literasi Sains Siswa SMA. Journal of Innovative Science Education. ISSN 2502-4523. Universitas Negeri Semarang

Bahriar, Evi S. 2012. Literasi Sains. evisapinatulbahriah.wordpress.com

Nisa, Arifatun.,dkk. 2015. Efektivitas Penggunan Modul Terintegrasi Etnosains dalam Pembelajaran Berbasis Masalah untuk Meningkatkan Literasi Sains Siswa . Unnes Scince Educational Journal ISSN 2252-6617. Universitas Negeri Semarang.

Oktariza, Yuvita. 2012. Literasi Sains, http://vivitmuzaki.wordpress.com/liter asi sains (9 april 2018)

Perwitasari, Titi.,dkk. 2016. Peningkatan Literasi Sains Melalui Pembelajaran Energi dan Perubahannya Bermuatan Etnosains pada Pengasapan Ikan. Jurnal Penelitian Pendidikan IPA JPPIPA, Vol 1 No.2 2016. Universitas Negeri Surabya

PPPPTK-SB Yogyakarta. 2013. Materi Pelatihan Implementasi Kurikulum 2013 untuk Pengawas Sekolah. Penerbit Kementerian Pendidikan dan Kebudayaan RI. Jakarta

Yuliati, Yuyu. 2017. Literasi Sains Dalam Pembelajaran IPA. Jurnal Cakrawala Pendas Vol. 3 No. 2 Edisi Juli 2017 eISSN: 2579-4442.

ScienceEdu Vol. I. No. 1 Desember 2018

Received 10 October 2018 | Received in revised form 11 November2018| Accepted 25 November 2018| Published online 31 December 2018 